\title{
Cross-sectional study of pattern of Dyslipidemia and Prevalence of Atherogenic Diabetic Dyslipidemia in newly detected Diabetic patients
}

\author{
Vinay Krishnamurthy', Akhila Rao Kerekoppa ${ }^{2}$, Prabhakar B ${ }^{3}$ \\ 1,2Senior Resident, Department of Internal Medicine, East Point College of Medical Sciences and Hospital, Bangalore, \\ Karnataka, India, ${ }^{3}$ Professor and Principal, Department of Internal Medicine, East Point College of Medical Sciences \\ and Hospital, Bangalore, Karnataka, India
}

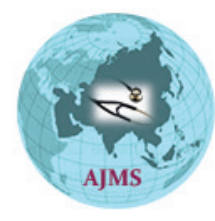

A B S T R A C T

\begin{abstract}
Background: India has seen an ever increasing number of diabetic patients and in turn rise in cardiovascular diseases. Many studies have shown diabetic patients to have dyslipidemia, with certain common patterns early in the disease. Aims and Objective: The current study was done to identify pattern of dyslipidemia and prevalence of ADD in treatment naïve diabetic patients. Material and Methods: Fasting lipid profile was analysed in treatment naïve diabetic patients at a tertiary care teaching hospital. Various factors influencing the results were analysed statistically. Results: Prevalence of dyslipidemia was $89.2 \%$, whereasatherogenic diabetic dyslipidemia was seen in $34.2 \%$ and raised non-HDL cholesterol in $73.3 \%$. Conclusion: Our study showed a high prevalence of dyslipidemia in newly diagnosed diabetics indicating the importance of screening for dyslipidemia in newly diagnosed cases and implementation of timely lipid lowering therapy to prevent CVD. It also highlights the importance of pattern of dyslipidemia called Atherogenic diabetic dyslipidemia and raised Non-HDL cholesterol in diabetic patients.
\end{abstract}

Access this article online

Website:

http://nepjol.info/index.php/AJMS DOI: 10.3126/ajms.v10i6.25633 E-ISSN: 2091-0576

P-ISSN: $2467-9100$

Key words: Atherogenic diabetic dyslipidemia; Dyslipidemia; Newly detected diabetes mellitus; Non HDL cholesterol; LDL; Triglycerides

\section{INTRODUCTION}

It is currently estimated that diabetes prevalence by 2030 will include 439 million adults worldwide. ${ }^{1}$ Cardiovascular disease (CVD) is the leading cause of death worldwide, and mortality due to CVD is higher in low- and middleincome countries. ${ }^{2,3}$ In India, there has been an alarming increase in the prevalence of CVD over the past two decades so much so that accounts for $24 \%$ of all deaths among adults aged 25-69 years. ${ }^{4}$ The risk for coronary artery disease (CAD) is 2-4 times higher in diabetic subjects, and in Indians, CAD occurs prematurely, i.e. one to two decades earlier than in the West. ${ }^{5}$ Dyslipidemia is an abnormally increased amount of lipids (e.g. cholesterol and/or triglycerides) and is one of the major risk factors for CVDs in Diabetes. Diabetic dyslipidemia consists of specifically mild to marked elevation of triglyceriderich lipoproteins- very low density lipoprotein-cholesterol (VLDL-C) and VLDL-C remnants, and low levels of high density lipoprotein-cholesterol (HDL-C). Raised serum triglycerides (TG) and low HDL-C often precede the onset of T2DM. In addition, low density lipoprotein cholesterol (LDL-C) particles are converted to smaller, perhaps more atherogenic, lipoproteins termed 'small dense LDL-C' (sd-LDL-C). ${ }^{6}$ This combination of hypertriglyceridemia, low HDL-C and high levels of LDL-C, termed as 'AtherogenicDyslipidemia' - better addressed as Atherogenic Diabetic Dyslipidemia (ADD), is particularly seen in Asian Indians. Although precise reason for such dyslipidemia is unknown, genetic predisposition and characteristic body composition (excess intraabdominal fat) may be important contributors. A common 
outcome of such a body composition and dyslipidemia in Asian Indians is the tendency to develop insulin resistance. ${ }^{7}$

A study by Parikh $\mathrm{R} \mathrm{M}$ et $\mathrm{al}^{8}$ found that the majority of Indian type 2 diabetics are dyslipidemic at baseline. Majority of these diabetic patients failed to achieve all standard goals of dyslipidemia management. In a substantial number of patients this was attributable to the fact that the HDL-C target was not met. ${ }^{8}$ Hence this study was done to identify pattern of dyslipidemia and prevalence of ADD in treatment naïve diabetic patients.

\section{MATERIALS AND METHODS}

This was cross sectional study carried on the patients attending the Medicine OPD of East Point College of Medical Sciences and Hospital, Bangalore during 6 months period of October 2018 to March 2019. Patients with type 2 diabetes mellitus visiting consecutively in the Medicine OPD were enrolled for this study. The patients enrolled in the study were newly detected Diabetes patients. The patients of type 1 diabetes mellitus were not considered for this study. The patients who were also suffering from coronary artery disease (CAD) or had history of cerebrovascular accident (CVA) or were diagnosed as having CAD or CVA after enrolment and those patients already taking statins or other drugs for lipid lowering were excluded from this study. Diabetic patients suffering from metabolic disorders or chronic systemic diseases were also excluded from the study. In those patients included in the study, detailed history was taken and clinical examination was done. The demographic parameters of the patients were recorded and their weight, height and BMI were recorded using standard methods. Fasting blood sample of the patients after at least 8 hours overnight fast was taken to measure serum lipid profile parameters of total cholesterol (TC), triglycerides (TG), low density lipid cholesterol (LDL-C) and high density lipid cholesterol (HDL-C). The cut-off normal values for individual lipid levels were taken as per guidelines of the National Cholesterol Education Program (NCEP) Expert Panel on Detection, Evaluation and Treatment of High Blood Cholesterol in Adults (Adult Treatment Panel III). The body mass index (BMI) was calculated by the Quetelet Index, BMI $=$ Weight $(\mathrm{Kg}) /$ Height $\left(\mathrm{m}^{2}\right)$ from weight and height measurements. The data of the individual patients was entered in the Microsoft Excel sheet and was analysed statistically using SPSS software. Prevelance and pattern of dyslipidemia was analysed in the study population. Various sociodemographic characters associated with dyslipidemia, atherogenic diabetic dyslipidemia and high Non-HDL cholesterol were analysed using appropriate statistical tests.

\section{RESULTS}

We studied a total of 120 patients, out of which $63(52 \%)$ of them were males and $57(48 \%)$ were females. Mean age of the patients was $47.8 \mathrm{yrs} .64(53.3 \%)$ patients were urban dwellers and $56(46.6 \%)$ were from rural areas. Prevalence of dyslipidemia was $89.2 \%$ with 107 patients having abnormalities in lipid profile either alone or in combination. Out of 107 patients, 60 were male and 47 were female with significant $\mathrm{p}$-value of 0.024. Dyslipidemia was highest in age group of 51-60 years $(n=39)$. It was higher among urban population with $55.1 \%(\mathrm{n}=59)$ prevalence. Prevalence of dyslipidemia was analysed with various variables as depicted in Table 1.

Atherogenic diabetic dyslipidemia defined as a combination of high TG, high LDL, low HDL, was seen in $34.2 \%(\mathrm{n}=41)$ of patients out of which $58.5 \%(\mathrm{n}=24)$ were males and $41.5 \%(\mathrm{n}=17)$ were females.56.1\% $(\mathrm{n}=23)$ were urban population and $43.9 \%(\mathrm{n}=18)$ were from rural areas. Atherogenic diabetic dyslipidemia had significant association ( $\mathrm{p}$ value $=0.036$ ) with Hypertension when compared with the other variables as depicted in Table 2.

Non-HDL-C was elevated in $73.3 \%(n=88)$ of the patients, out of which $53.3 \%(\mathrm{n}=46)$ were males and $47.7 \%(\mathrm{n}=42)$ were females. Among the total 88 patients $56.8 \%(\mathrm{n}=50)$ were urban population and $43.2 \%(\mathrm{n}=38)$ were rural population. Among patients having elevated nonHDL-C, increasing BMI and higher waist circumference showed significant association with $\mathrm{p}$-values of $<0.001$ and 0.027 respectively as depicted in Table 3 .

The various sociodemographic details associated with dyslipidemia are detailed below in Table 4.

Prevalence of Atherogenic Diabetic Dyslipidemia (ADD) was $34.2 \%$ in our study On comparing different lipid parameters with the diabetic control status, only ADD had significant correlation with poor glycemic control $(\mathrm{HbA1c}>8)$ with a significant $\mathrm{p}$-value as depicted in Table 5.

\section{DISCUSSION}

According to IDF Diabetes Atlas Update 2017,425 million people have diabetes worldwide and half of the people with diabetes remain undiagnosed and two-thirds i.e. 279 million live in the urban areas. ${ }^{10}$ Patients with DM have a 2- to 4-fold increased risk of cardiovascular, peripheral vascular and cerebrovascular disease, which are the leading causes of morbidity and mortality in this population. Many Western epidemiological studies have shown an association between diabetic dyslipidemia, which is characterized 


\begin{tabular}{|c|c|c|c|c|c|c|}
\hline \multirow[t]{3}{*}{ Variable } & \multirow[t]{3}{*}{ No. of patients } & \multicolumn{4}{|c|}{ Dyslipidemia } & \multirow[t]{3}{*}{$P$ value } \\
\hline & & \multicolumn{2}{|c|}{ Absent } & \multicolumn{2}{|c|}{ Present } & \\
\hline & & n & $\%$ & $\mathbf{n}$ & $\%$ & \\
\hline BMI & & & & & & 0.291 \\
\hline Normal & 19 & 3 & 15.8 & 16 & 84.2 & \\
\hline Over Weight & 52 & 3 & 5.8 & 49 & 94.2 & \\
\hline Obese & 49 & 7 & 14.3 & 42 & 85.7 & \\
\hline Waist circumference & & & & & & 0.502 \\
\hline Normal & 28 & 4 & 14.3 & 24 & 85.7 & \\
\hline Abnormal & 92 & 9 & 9.8 & 83 & 90.2 & \\
\hline Smoking habit & & & & & & 0.114 \\
\hline Absent & 89 & 12 & 13.5 & 77 & 86.5 & \\
\hline Present & 31 & 1 & 3.2 & 30 & 96.8 & \\
\hline Alcohol consumption & & & & & & 0.223 \\
\hline Absent & 84 & 11 & 13.1 & 73 & 86.9 & \\
\hline Present & 36 & 2 & 5.6 & 34 & 94.4 & \\
\hline Hypertension & & & & & & 0.552 \\
\hline Absent & 74 & 9 & 12.2 & 65 & 87.8 & \\
\hline Present & 46 & 4 & 8.7 & 42 & 91.3 & \\
\hline
\end{tabular}

\begin{tabular}{|c|c|c|c|c|c|c|}
\hline & & \multicolumn{4}{|c|}{$\begin{array}{c}\text { Atherogenic diabetic } \\
\text { dyslipidemia }\end{array}$} & \multirow[t]{3}{*}{$\begin{array}{c}P \\
\text { value }\end{array}$} \\
\hline & \multirow[t]{2}{*}{$\mathbf{N}$} & \multicolumn{2}{|c|}{ No } & \multicolumn{2}{|c|}{ Yes } & \\
\hline & & $\mathbf{n}$ & $\%$ & $\mathrm{n}$ & $\%$ & \\
\hline BMI & & & & & & 0.422 \\
\hline Normal & 19 & 15 & 78.9 & 4 & 21.1 & \\
\hline Over Weight & 52 & 33 & 63.5 & 19 & 36.5 & \\
\hline Obese & 49 & 31 & 63.3 & 18 & 36.7 & \\
\hline $\begin{array}{l}\text { Waist } \\
\text { circumference }\end{array}$ & & & & & & 0.105 \\
\hline Normal & 28 & 22 & 78.6 & 6 & 21.4 & \\
\hline Abnormal & 92 & 57 & 62.0 & 35 & 38.0 & \\
\hline $\begin{array}{l}\text { Smoking } \\
\text { habit }\end{array}$ & & & & & & 0.290 \\
\hline Absent & 89 & 61 & 68.5 & 28 & 31.5 & \\
\hline Present & 31 & 18 & 58.1 & 13 & 41.9 & \\
\hline Alcohol & & & & & & 0.120 \\
\hline consumption & 84 & 59 & 70.2 & 25 & 29.8 & \\
\hline $\begin{array}{l}\text { Absent } \\
\text { Present }\end{array}$ & 36 & 20 & 55.6 & 16 & 44.4 & \\
\hline Hypertension & & & & & & 0.036 \\
\hline Absent & 74 & 54 & 73.0 & 20 & 27.0 & \\
\hline Present & 46 & 25 & 54.3 & 21 & 45.7 & \\
\hline
\end{tabular}

by hypertriglyceridemia; low levels of HDL cholesterol; postprandial lipemia and small, dense LDL cholesterol particles and the occurrence of cardiovascular disease. ${ }^{11-13}$

The 'Chennai Urban Population Study' showed 11\% prevalence of CAD, which is 10 times more than what it was in 1970. Clustering of risk factors for CAD such as hyperglycemia, central obesity, dyslipidemia, and hypertension (HTN) tend to occur, and, interplay of these risk factors could explain the enhanced CAD risk in Indians. Additionally, low-grade inflammation and a possible inherent genetic susceptibility are other contributing factors. ${ }^{14}$

\begin{tabular}{|c|c|c|c|c|c|c|}
\hline & \multicolumn{5}{|c|}{ Raised Non HDL-C } & \multirow{3}{*}{$\begin{array}{c}\mathbf{P} \\
\text { value }\end{array}$} \\
\hline & \multirow[t]{2}{*}{$\mathbf{N}$} & \multicolumn{2}{|c|}{ Absent } & \multicolumn{2}{|c|}{ Present } & \\
\hline & & $\mathrm{n}$ & $\%$ & $n$ & $\%$ & \\
\hline BMI & & & & & & $<0.001$ \\
\hline Normal & 19 & 12 & 63.2 & 7 & 36.8 & \\
\hline Over weight & 52 & 10 & 19.2 & 42 & 80.8 & \\
\hline Obese & 49 & 10 & 20.4 & 39 & 79.6 & \\
\hline $\begin{array}{l}\text { Waist } \\
\text { circumference }\end{array}$ & & & & & & 0.027 \\
\hline Normal & 28 & 12 & 42.9 & 16 & 57.1 & \\
\hline Abnormal & 92 & 20 & 21.7 & 72 & 78.3 & \\
\hline Smoking habit & & & & & & 0.285 \\
\hline Absent & 89 & 26 & 29.2 & 63 & 70.8 & \\
\hline Present & 31 & 6 & 19.4 & 25 & 80.6 & \\
\hline $\begin{array}{l}\text { Alcohol } \\
\text { consumption }\end{array}$ & & & & & & 0.105 \\
\hline Absent & 84 & 26 & 31.0 & 58 & 69.0 & \\
\hline Present & 36 & 6 & 16.7 & 30 & 83.3 & \\
\hline Hypertension & & & & & & 0.165 \\
\hline Absent & 74 & 23 & 31.1 & 51 & 68.9 & \\
\hline Present & 46 & 9 & 19.6 & 37 & 80.4 & \\
\hline
\end{tabular}

Our study showed a high prevalence of dyslipidemia of $89.2 \%$ among the 120 patients enrolled of which $56.1 \%$ were males and $43.9 \%$ were females which were statistically significant. In our study prevalence was higher in urban population with $92 \%$ of newly detected diabetics being dyslipidemic compared to $85 \%$ in the rural diabetics. According to ICMR INDIAB study, prevalence of dyslipidemia was $79 \%$ and there was no urban rural difference observed in the four regions studied in ICMR study. $^{15}$

Most of subjects of our study had mixed pattern of dyslipidemia. On analysis of Individual parameters, total cholesterol was elevated in $43.3 \%(n=52)$ of patients, 


\begin{tabular}{|c|c|c|c|c|c|c|c|c|c|c|}
\hline \multirow{2}{*}{$\begin{array}{l}\text { Serum } \\
\text { Lipid }\end{array}$} & \multirow[t]{2}{*}{ Gender } & \multicolumn{3}{|c|}{ Age (yrs) } & \multicolumn{2}{|c|}{ DM } & \multicolumn{2}{|c|}{ Obesity } & \multicolumn{2}{|c|}{ Hypertension } \\
\hline & & $\begin{array}{c}<45 \\
(\mathrm{~N}=43)\end{array}$ & $\begin{array}{l}45-60 \\
(N=68)\end{array}$ & $\begin{array}{l}>60 \\
(N=9)\end{array}$ & $\begin{array}{l}\text { Controlled } \\
(\mathrm{N}=46)\end{array}$ & $\begin{array}{l}\text { Uncontrolled } \\
(\mathrm{N}=74)\end{array}$ & $\begin{array}{l}\text { Overweight } \\
(\mathrm{N}=52)\end{array}$ & $\begin{array}{l}\text { Obese } \\
(\mathrm{N}=49)\end{array}$ & $\begin{array}{c}\text { No } \\
(N=74)\end{array}$ & $\begin{array}{c}\text { Yes } \\
(\mathrm{N}=46)\end{array}$ \\
\hline \multirow{4}{*}{$\begin{array}{l}\mathrm{TC}>=200 \\
\mathrm{mg} / \mathrm{dL}\end{array}$} & Male & 11 & 17 & 1 & 5 & 24 & 14 & 13 & 19 & 10 \\
\hline & Female & 5 & 15 & 3 & 5 & 18 & 10 & 10 & 14 & 9 \\
\hline & Total & 16 & 32 & 4 & 10 & 42 & 24 & 23 & 33 & 19 \\
\hline & $\%$ & $37.2 \%$ & $47.1 \%$ & $44.4 \%$ & $21.7 \%$ & $56.8 \%$ & $46.2 \%$ & $46.9 \%$ & $44.6 \%$ & $41.3 \%$ \\
\hline \multirow{4}{*}{$\begin{array}{l}\mathrm{TG}>=150 \\
\mathrm{mg} / \mathrm{dL}\end{array}$} & Male & 17 & 28 & 2 & 17 & 30 & 22 & 21 & 28 & 19 \\
\hline & Female & 11 & 22 & 3 & 15 & 21 & 17 & 14 & 17 & 19 \\
\hline & Total & 28 & 50 & 5 & 32 & 51 & 39 & 35 & 45 & 38 \\
\hline & $\%$ & $65.1 \%$ & $73.5 \%$ & $55.6 \%$ & $69.6 \%$ & $68.9 \%$ & $75.0 \%$ & $71.4 \%$ & $60.8 \%$ & $82.6 \%$ \\
\hline \multirow{4}{*}{$\begin{array}{l}\mathrm{HDL}<40 \\
\mathrm{mg} / \mathrm{dL}\end{array}$} & Male & 12 & 26 & 2 & 14 & 26 & 19 & 15 & 24 & 16 \\
\hline & Female & 8 & 17 & 1 & 8 & 18 & 13 & 8 & 13 & 13 \\
\hline & Total & 20 & 43 & 3 & 22 & 44 & 32 & 23 & 37 & 29 \\
\hline & $\%$ & $46.5 \%$ & $63.2 \%$ & $33.3 \%$ & $47.8 \%$ & $59.5 \%$ & $61.5 \%$ & $46.9 \%$ & $50.0 \%$ & $63.0 \%$ \\
\hline \multirow{4}{*}{$\begin{array}{l}\mathrm{LDL}>=100 \\
\mathrm{mg} / \mathrm{dL}\end{array}$} & Male & 13 & 27 & 3 & 13 & 30 & 22 & 19 & 25 & 18 \\
\hline & Female & 8 & 19 & 4 & 9 & 22 & 14 & 12 & 20 & 11 \\
\hline & Total & 21 & 46 & 7 & 22 & 52 & 36 & 31 & 45 & 29 \\
\hline & $\%$ & $48.8 \%$ & $67.6 \%$ & $77.8 \%$ & $47.8 \%$ & $70.3 \%$ & $69.2 \%$ & $63.3 \%$ & $60.8 \%$ & $63.0 \%$ \\
\hline
\end{tabular}

\begin{tabular}{|c|c|c|c|}
\hline \multirow{2}{*}{$\begin{array}{l}\text { Atherogenic diabetic } \\
\text { dyslipidemia }\end{array}$} & \multicolumn{2}{|c|}{ HbA1c } & \multirow[t]{2}{*}{ Total } \\
\hline & $<=8$ & $>8$ & \\
\hline \multirow{2}{*}{ NO } & 35 & 44 & 79 \\
\hline & $44.3 \%$ & $55.7 \%$ & $100.0 \%$ \\
\hline \multirow[t]{2}{*}{ YES } & 11 & 30 & 41 \\
\hline & $26.8 \%$ & $73.2 \%$ & $100.0 \%$ \\
\hline \multirow[t]{2}{*}{ Total } & 46 & 74 & 120 \\
\hline & $38.3 \%$ & $61.7 \%$ & $100.0 \%$ \\
\hline
\end{tabular}

triglycerides was elevated in $67.5 \%(\mathrm{n}=81), \mathrm{LDL}$ was elevated in $60 \%(\mathrm{n}=72)$, elevated non-HDL was found in $73.3 \%(n=88)$ and low HDL was found in $55 \%(n=66)$ of the patients. Hence the most frequent lipid abnormality was elevated non-HDL levels suggesting importance of non-HDL cholesterol to be used as co-primary target for therapeutic interventions along with primary LDL targets especially in patients with TGs in range of 200-500 as suggested by Lipid association of India guidelines. ${ }^{16}$ The result of the study done by Dixit et al indicates that the most common recognized abnormality was hypertriglyceridemia. ${ }^{17}$ Abbate and Brunzell reported that the increase in triglycerides in poorly controlled patients was related to the decrease of activities of adipose tissue and muscle lipoprotein lipase activity. ${ }^{18}$

According to ICMR-INDIAB increased TC was $13.9 \%$, increased TG in $29.5 \%$, low HDL was the most common abnormality with $72.3 \%$ and high LDL in $11.8 \%, 4.8 \%$ of patients had all four lipid abnormalities in form of high TC, high TG, high LDL and low HDL. ${ }^{15}$ Our study showed much higher prevalence of $28 \%$ for the four lipid abnormalties mentioned above. In our study, most of the diabetic patients had mixed dyslipidemia i.e. more than one lipid abnormality. The most common mixed abnormality detected was hypertriglyceridemia and low HDL levels $(41.6 \%)$ which was in similarity with the western studies where similar pattern was observed, ${ }^{19}$ whereas study done by Pandya et al among the Gujarati population showed that the most common mixed lipid abnormality was high TG and high LDL. ${ }^{20}$

Prevalence of Atherogenic Diabetic Dyslipidemia(ADD) was $34.2 \%$ in our study which was comparable to study done by Parikh et al where the prevalence of ADD was $36.1 \%$. On comparing different lipid parameters with the diabetic control status, only ADD had significant correlation with poor glycemic control (HbA1c $>8$ ) with a significant p-value. Hence control of diabetes is of prime importance, as it can lead to reduced incidence of Atherogenic Diabetic dyslipidemia.

In recent times the focus is shifting on reducing the non-HDL-C (all the atherogenic lipoproteins), as many trials have demonstrated non-HDL-C levels as a better predictor of CVD risk than is LDL-C. LDL-C may actually be underestimating the burden of atherogenic, cholesterol-carrying lipoproteins. Our study had significant correlation of non-HDL cholesterol with BMI and waist circumference.

\section{CONCLUSION}

Our study showed a high prevalence of dyslipidemia at $89.2 \%$ in newly diagnosed diabetics indicating the importance of screening for dyslipidemia in newly diagnosed cases and institution of timely lipid lowering 
therapy to prevent ASCVDs. Our study also highlights the importance of pattern of dyslipidemia called Atherogenic diabetic dyslipidemia and raised Non-HDL cholesterol which is shown to have higher prevalence in our study. Non HDL-C is now being set as co-primary target especially in patients with triglyceride levels of more than $200 \mathrm{mg} / \mathrm{dl}$, indicating the role of newer combined PPAR $\alpha / \gamma$ agonists which are effective in managing lipids and insulin sensitization that control hyperglycemia simultaneously, when the LDL and Non-HDL targets are not reached even after optimum dose of statins. Hence it is of paramount importance to aim for strict goals, specific thresholds, early and regular screening for dyslipidemia in Indian diabetics so that early, prompt and appropriate preventive measures can be instituted to reduce the occurrence of Atherosclerotic cardiovascular diseases.

\section{REFERENCES}

1. Shaw JE, Sicree RA and Zimmet PZ. Global estimates of the prevalence of diabetes for 2010 and 2030. Diabetes Res ClinPract 2010;87(1):4-14.

2. World Health Organization. The Global Burden of Disease: 2004 Update. 2008; 11-12.

3. Fuster $\mathrm{V}$ and Kelly BB. Promoting Cardiovascular Health in the Developing World: A Critical Challenge to Achieve Global Health. Washginton, DC: National Academies Press, 2010.

4. Sample Registration System. Million Death Study: Preliminary Report on Causes of Death in India 2001-2003. New Delhi: Registrar General of India, 2007.

5. Enas EA, Yusuf $S$ and Mehta J. Prevalence of coronary artery disease in Asian Indians. Am J Cardiol 1992; 70: 945-949.

6. Muačević-Katanec $D$ and Reiner Z. Diabetic dyslipidemia or 'diabetes lipidus'? Expert Rev Cardiovasc Ther 2011; 9(3):341348.

7. Misra A, Luthra K and Vikram NK. Dyslipidemia in Asian Indians: determinants and significance. J Assoc Physicians India 2004;52:137-142.

8. Parikh RM, Joshi SR, Menon PS and Shash NS. Prevalence and pattern of diabetic dyslipidemia in Indian type 2 diabetic patients.
Diabetes Metab Syndr 2010;4(1):10-12.

9. National Cholesterol Education Program (NCEP) Expert Panel on Detection, Evaluation, and Treatment of High Blood Cholesterol in Adults (Adult Treatment Panel III) Third Report of the National Cholesterol Education Program (NCEP) Expert Panel on Detection, Evaluation, and Treatment of High Blood Cholesterol in Adults (Adult Treatment Panel III. Circulation. 2002; 106(25):3143-3121.

10. International Diabetes Federation. IDF Diabetes Atlas, $8^{\text {th }}$ edn. Brussels, Belgium: International Diabetes Federation, 2017. http://www.diabetesatlas.org

11. Campos H, Moye LA, Glasser SP, Stampfer MJ and Sacks FM. Low-density lipoprotein size, pravastatin treatment, and coronary events. JAMA 2001; 286(12):1468-1474.

12. Sacks FM and Campos H. Cardiovascular endocrinology: Low-density lipoprotein size and cardiovascular disease: a reappraisal. J Clin Endocrinol Metab 2003;88(10):4525-4532.

13. Jungner I, Sniderman AD, Furberg $C$, Aastveit $A H$, Holme I and Walldius $G$. Does low-density lipoprotein size add to atherogenic particle number in predicting the risk of fatal myocardial infarction? Am J Cardiol 2006; 97(7):943-946.

14. Mohan V, Venkatraman JV and Pradeepa R. Epidemiology of cardiovascular disease in type 2 diabetes: The Indian scenario. J Diabetes Sci Technol 2010;4(1):158-170.

15. Anjana RM, Pradeepa R, Deepa M, Datta M, Sudha V, Unnikrishnan R, et al. Prevalence of diabetes and prediabetes (impaired fasting glucose and/or impaired glucose tolerance) in urban and rural India: phase I results of the Indian council of medical research-INdiaDIABetes (ICMR-INDIAB) study. Diabetologia 2011; 54(12):3022-3027.

16. Expert Consensus Panel. The Lipid Association of India (LAI) Expert Consensus Statement on Management of Dyslipidemia in Indians 2016: Part 1. J Assoc Phy Ind 2016; Suppl 1; S1-52.

17. Dixit AK, Dey R, Suresh A, Chaudhuri S, Panda AK, Mitra A, et al. The prevalence of dyslipidemia in patients with diabetes mellitus of ayurveda Hospital. J Diab Metab Dis 2014;13:58.

18. Abbate SL and Brunzell JD. Pathophysiology of hyperlipidemia in diabetes.J Cardiovasc Pharmacol 1990; 16:1-7.

19. U.K. Prospective Diabetes Study.Plasma lipids and lipoproteins at diagnosis of NIDDM by age and sex. Diabetes Care.1997;20(11):1683-1687.

20. Pandya H, Lakhani JD, Dadhania A and Trivedi A. The Prevalence and Pattern of Dyslipidemia among Type 2 Diabetic Patients at Rural Based Hospital in Gujarat, India. Ind J ClinPrac 2012; 22(12): 36-44.

\footnotetext{
Authors Contribution:

VK-Concept and design of the study, collected data, prepared first draft of manuscript; ARK- Concept and design of the study, collected data, statistically analyzed and interpreted, prepared first draft of manuscript; PB-Concept and design of the study, critical revision of the manuscript

Work attributed to:

Department of General Medicine, East Point College of Medical Sciences and Hospital, Bangalore, Karnataka, India.

Orcid ID:

Dr. Vinay Krishnamurthy - (1) http://orcid.org/0000-0002-8936-0605

Dr. Akhila Rao Kerekoppa - (i) https://orcid.org/0000-0001-6432-9962

Dr. Prabhakar B - (i) https://orcid.org/0000-0002-9171-6877

Source of Support: Nil, Conflict of Interest: On behalf of all authors, the corresponding author states that there is no conflict of interest.
} 